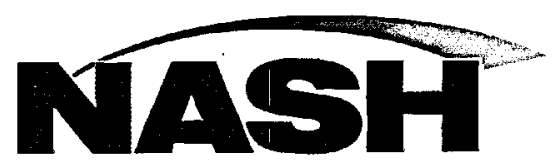

A Gardner Denver Product

\title{
Gas Extraction Systems for Geothermal Power Plants
} 2006

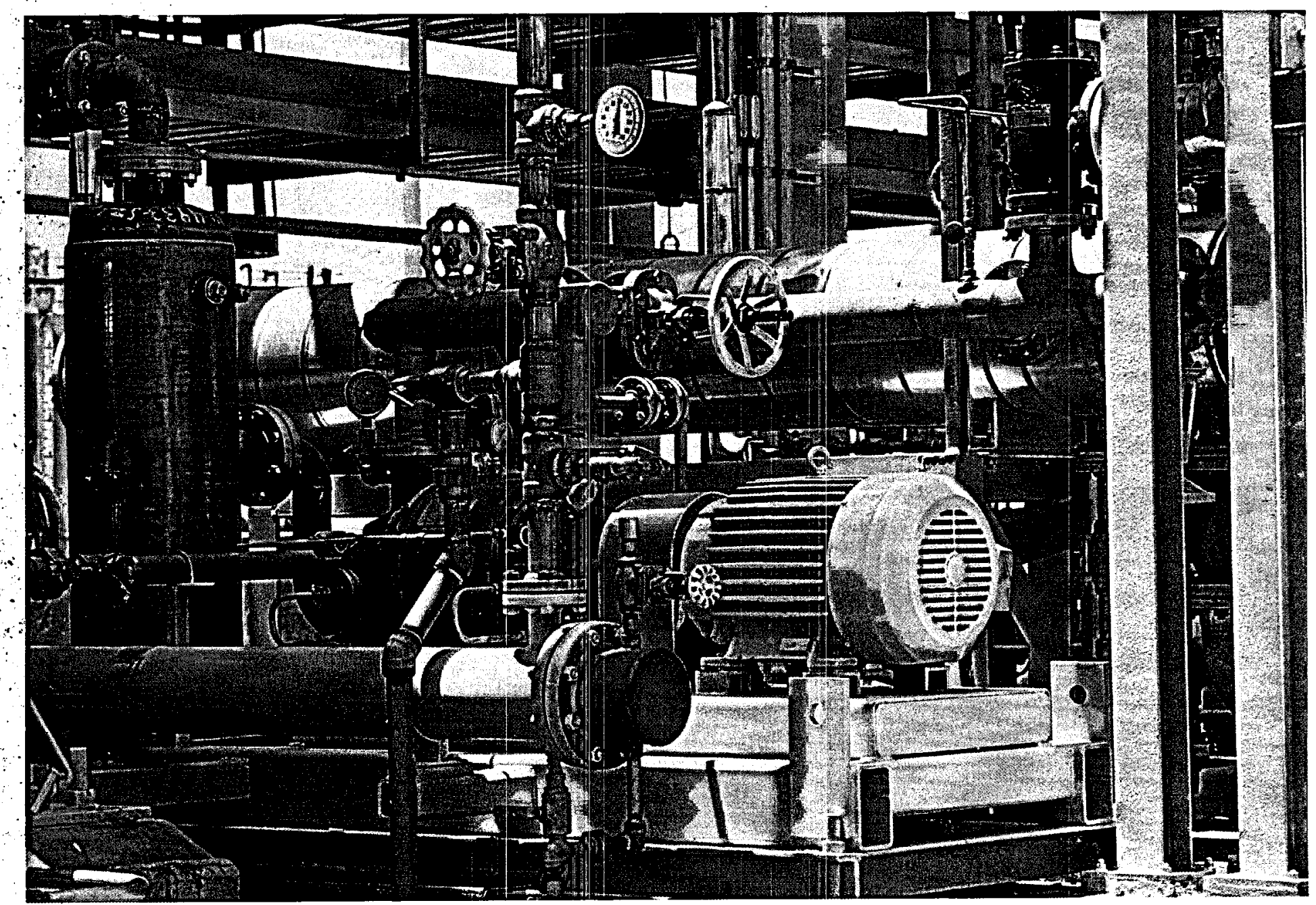

Steam jet/vacuum hybrid system by Gardner Denver Nash at a U.S. Geothermal Power Station 


\section{DISCLAIMER}

This report was prepared as an account of work sponsored by an agency of the United States Government. Neither the United States Government nor any agency Thereof, nor any of their employees, makes any warranty, express or implied, or assumes any legal liability or responsibility for the accuracy, completeness, or usefulness of any information, apparatus, product, or process disclosed, or represents that its use would not infringe privately owned rights. Reference herein to any specific commercial product, process, or service by trade name, trademark, manufacturer, or otherwise does not necessarily constitute or imply its endorsement, recommendation, or favoring by the United States Government or any agency thereof. The views and opinions of authors expressed herein do not necessarily state or reflect those of the United States Government or any agency thereof. 


\section{DISCLAIMER}

Portions of this document may be illegible in electronic image products. Images are produced from the best available original document. 


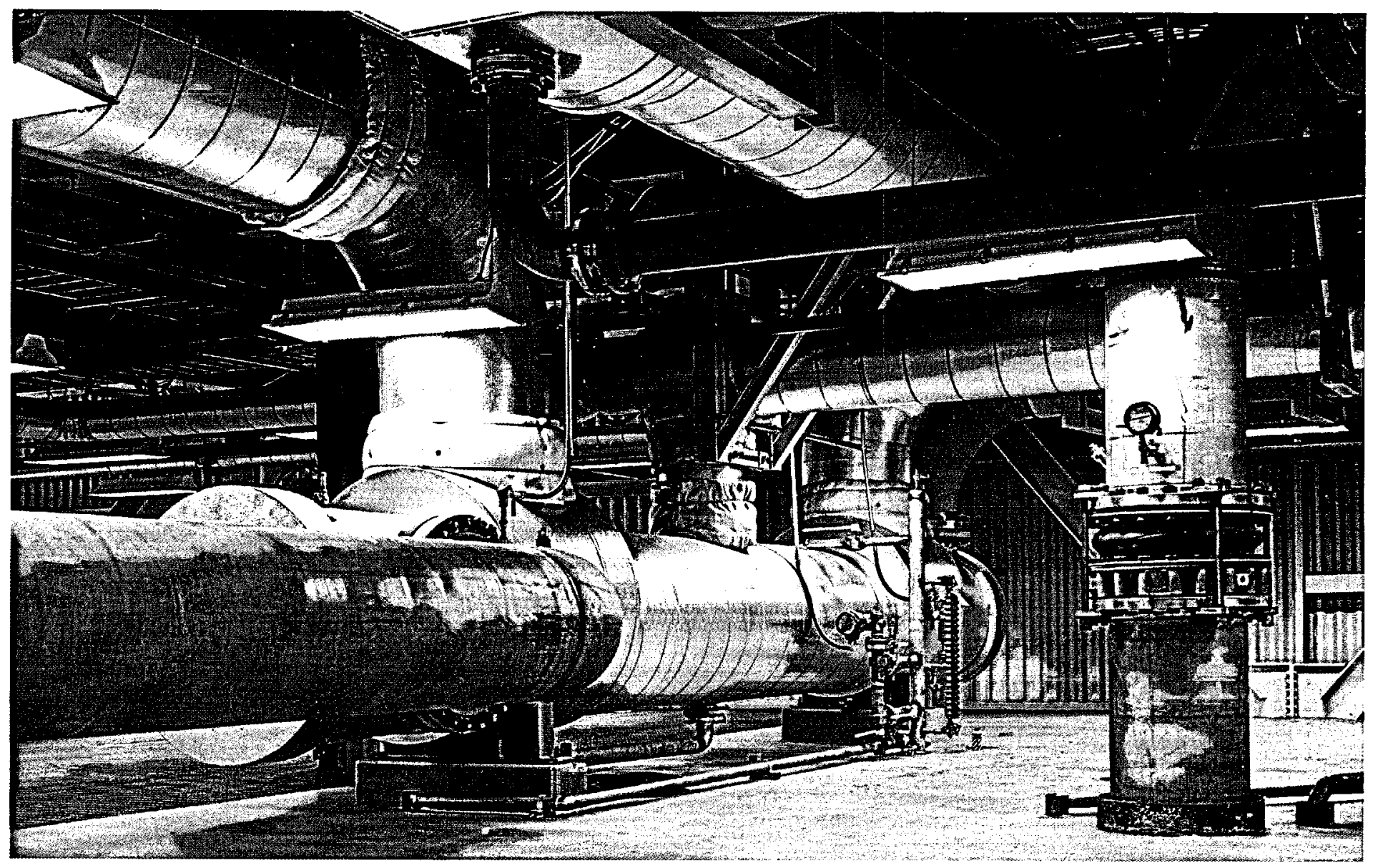

Two-stage Gardner Denver Nash steam ejector system at Santa Fe Geothermal Plant

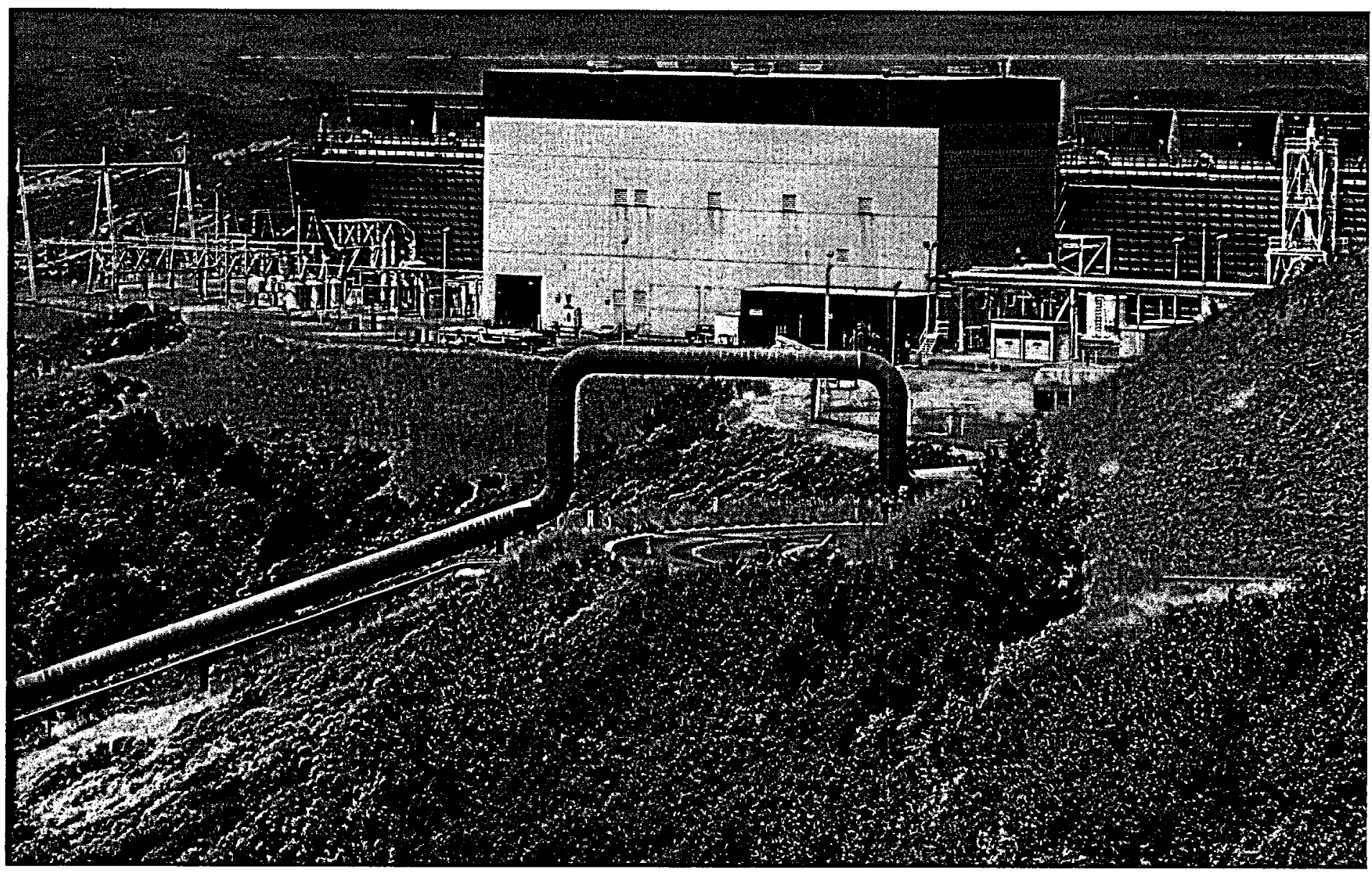




\section{Table of Contents}

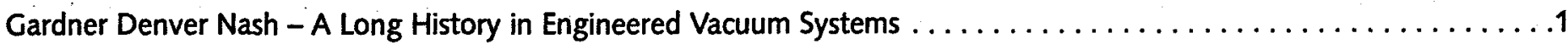

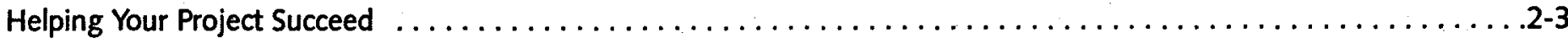

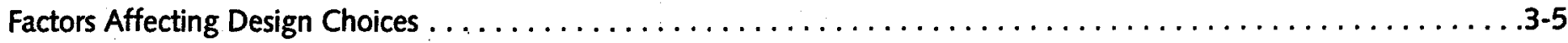

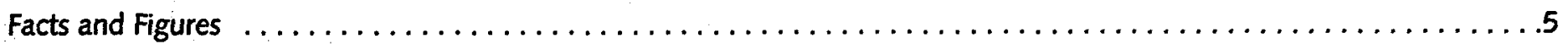

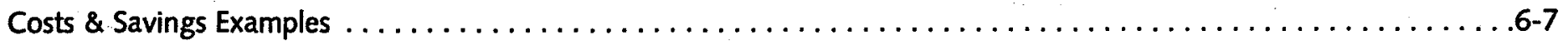

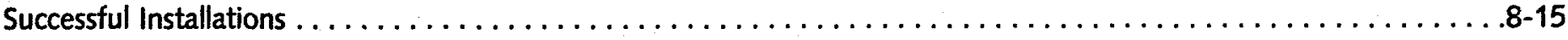

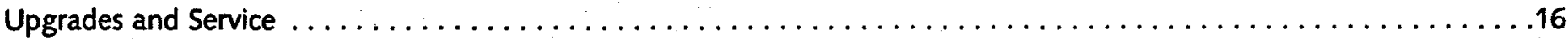

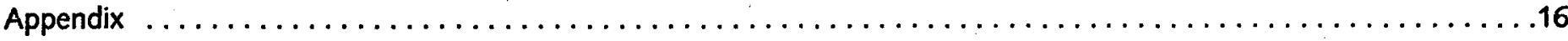

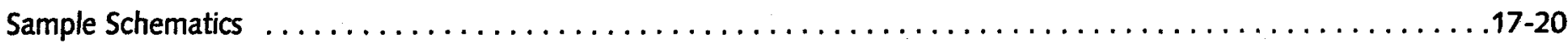

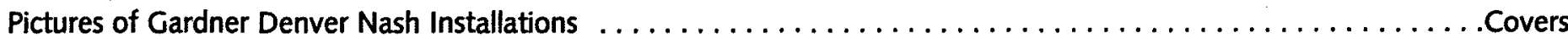

\section{A Long History in Vacuum Systems}

Gardner Denver Nash carries forward geothermal power experience that dates from the late 1950's and early 1960's. During that period, engineers of the Elliot Company devoted intensive study to pioneering the design and sizing of condenser gas extraction systems for the Geysers project in California.

When Elliot left the steam-jet ejector business in the midseventies, several of these key engineers founded their own firm under the name of Kinema, Inc., to continue the design and production of steam-jet ejector systems.

\section{The Nash Connection}

During the 1980's, The Nash Engineering Company began working with various ejector manufacturers to combine ejectors with Nash vacuum pumps into what is commonly called "Hybrid Systems". In order to handle this work with unified engineering and total system responsibility, Nash acquired Kinema, Inc. as a wholly-owned subsidiary in 1986.

\section{The elmo Connection}

During the 1990's Siemens elmo began offering Hybrid systems for geothermal gas extraction.

In 2002 Nash and elmo merged, forming a new company called nash_elmo. nash_elmo continued to offer hybrid sys- tems to the geothermal power industry using all available technologies.

In 2004 nash_elmo was acquired by Gardner Denver and became $\mathrm{NASH}_{\bar{H}}$, Liquid Ring Pump Division of Gardner Denver. We continue our commitment to provide gas extraction systems that meet or exceed performance requirements of geothermal power plants around the world.

\section{The Gardner Denver Nash Commitment}

Gardner Denver Nash is committed to one endeavor: the design and development of the best vacuum and compressed gas technology in the world. We devote all our energies, all of our investment, and all of our research and development activities toward this goal.

Gardner Denver Nash is committed to providing gas extraction systems that meet or exceed performance specifications for geothermal power plants around the world.

The performance and reliability of Gardner Denver Nash systems have become worldwide standards against which the products of other manufacturers are measured. 


\section{Gardner Denver Nash's geothermal experience will help your project succeed}

Superior design capabilities, highest quality, and most efficient equipment for extracting non-condensable gases from your condensers are critical for your plant's on-line operation and efficiency.

\section{Your entire plant depends on vacuum}

The condenser gas extraction systems must operate continuously. When any part of these systems fail for any reason, your plant's power output is lost.

Inability to handle the non-condensable load can cause the turbine to trip off-line with a corresponding loss of power and saleable electricity. You need the most reliable gas extraction system you can find.

\section{Efficiency}

Excessive steam consumption by the extraction systems can shorten the life of your field prematurely. The argument for the most efficient extraction system soon becomes obvious. In addition, the energy required for these extraction systems is not available as saleable power output, and thus, imposes an immediate economic loss.

\section{Flexibility}

Despite all efforts to predict and to control their behavior, geothermal fields are subject to the whims of nature. The amount and composition of non-condensable gases in the steam can change. So can steam pressure. Drilling more wells may remedy some deficiencies, but their characteristics cannot be predicted with certainty. Even cooling water temperature and availability are subject to change at some locations. All of these possibilities complicate the tasks of selecting and designing the right systems and equipment. The gas extraction systems must be designed to be flexible enough to adapt to changing site conditions.

\section{Expert engineering pays off}

The success that Gardner Denver Nash has achieved in this environment of shifting requirements is based on many years of engineering and application experience. We have seen what can happen at geothermal plants, and we have learned the most effective and economical ways to deal with the need for Reliability, Efficiency, and Flexibility. We apply this experience when we do the original design work and also when we modify systems in response to changed conditions.

\section{Meeting your specifications}

When we prepare our initial proposals, we base our calculations on rigorously honest appraisals and assumptions. As a result, when Gardner Denver Nash installations go into service turbine backpressure meets or exceeds specifications.

\section{Controlling costs}

We offer you a realistic way to control costs. We can supply a number of vacuum systems to meet a given set of requirements. Although all of them will perform to specifications, some will cost far less to purchase and to install. Others will utilize steam, cooling water, and electric power more efficientl As might be expected, the choices that conserve the most energy tend to cost more; but they will normally provide fast payback on the added investment. The number of possible combinations makes selecting the best one a complicated process - one that will be influenced by your own individual situation.

When you let us know your financial objectives, we will propose a system that will meet those objectives and enable you to plan your budgets with confidence. We will balance initial costs against low utility costs and low maintenance costs at the point you select. Gardner Denver Nash then provides you wit the necessary commercial and technical information to make the most informed decision.

\section{Performance}

Gardner Denver Nash equipment performs to specifications, with a reliability unequaled in the field. The steam-jet ejectors condensers, vacuum pumps and controls that we assemble for your system are designed and built to operate efficiently for years without interruption under the actual conditions you wil experience at your plant.

\section{Two-year warranty}

Gardner Denver Nash protects you with a two-year warranty that covers all equipment components and the entire system.

\section{You get the best service}

Wherever in the world your plant may be located, Gardner Denver Nash delivers fast, skilled technical help. Our trained engineers will be present at startup and commissioning to make sure that all of our systems perform as they should. We will assist in training your operations staff so they can become totally familiar with the workings of our Gardner Denver Nash extraction systems.

After the plant has been operating for a while, we will visit and help diagnose any problems that may have shown up. And $w$ will respond immediately to any emergency. This is all possible because of the Gardner Denver Nash global organization. 


\section{Geothermal field changes}

Because the energy source of a geothermal power plant seldom remains constant over the years, your power station's operating efficiency may decline for any one of many reasons. We can often suggest modifications in our gas extraction systems that will restore optimum power and efficiency to the generating unit.

Our vacuum specialists can make the necessary measurements to evaluate your operating conditions without shutting down or interrupting electric power output. They will be able to tell you what modifications will be advantageous to you. Sometimes, all that is necessary may be a simple change, such as control setting. If, however, equipment modification or replacement will be involved, our engineers will let you know in advance how much it will cost. The will give you a reliable prediction of the operating improvement you can expect to achieve. Thus, you will have all the information you need to calculate a payback time and to arrive at a sound decision about the desirability and the timing of a possible upgrade.

\section{Factors that affect system design choices}

Condenser gas extraction systems for geothermal plants perform the same function as condenser exhausters in fossilfueled generating stations; but they are quite different. Because steam from geothermal fields contains such great quantities of non-condensable gases compared with what is found in a closed-circuit boiler-water system, capacities must be far larger. The amount of gas to be handled is never exactly predictable, and it is not a clean mixture. Among other mineral compounds, it contains carbon dioxide and sulfides, which make it corrosive. It often carries silica, which precipitates out and builds up in piping and equipment.

System design begins with the best available prediction of how much $\mathrm{CO}_{2}$ and other non-condensable gases the steam from the field will bring into the turbine. The temperature, quality, and cost of available cooling water will affect system design decisions. So will any restrictions on the disposal of polluted water.

\section{The system components}

All gas extraction systems require condensers. While noncondensables from the main condenser are being compressed to atmospheric pressure, a substantial amount of the moisture they carry becomes condensable. It is cooled between stages of compression with inter-condensers and disposed of as a liquid. Both direct-contact barometric condensers and shell-and-tube surface condensers are used in gas extraction systems for geothermal plants. The choice of condenser type depends on environmental considerations.

While direct-contact condensers are more efficient and less costly, they do mix cooling water with geothermal steam. These systems utilize cooling towers for water recirculation, and may re-inject effluent water back into the earth to prevent pollution.
While surface condensers cost more, they keep clean cooling water separate from geothermal condensate. Pollution problems and cooling tower maintenance are minimized.

Steam-jet ejectors are the most widely used of all gas-compressing devices for gas extraction at geothermal plants. They are relatively inexpensive. They use the field steam directly as their motive energy source, and they have no moving parts. The main disadvantage of steam-jet ejectors is their inflexibility to meet widely changing pressure or flow requirements and their high consumption of valuable steam.

Gardner Denver Nash vacuum pumps are motor-driven, and they use this mechanical energy efficiently. Their operating characteristic enables them to adapt to changes in pressure and flow requirements.

Gardner Denver Nash is the world's leading supplier of vacuum pumps used for condenser exhausting at fossil-fueled power plants. But, the huge quantities of both condensable and noncondensable vapors that must be handled at geothermal plants would require many large vacuum pumps, which would be unattractive from a capital investment stand point. A good engineering and economic compromise is to use ejectors in the higher vacuum ranges where a large amount of condensables exist, and to use Gardner Denver Nash vacuum pumps in the middle-to-lower vacuum ranges, where those condensables have been reduced to condensate. This is why the vacuum pumps are staged with steam-jet ejectors and called "hybrid systems".

Turbo-compressors may be driven by separate steam turbines, through speed-increasing gears by separate motors, or by the main turbines through auxiliary gear sets. They are relatively efficient in their use of energy. However, these high-speed machines are suitable primarily for clean, dry gas compression. They have not proven to be reliable for this 
application without continuous, expensive and sophisticated preventative maintenance programs.

Geothermal gas extraction is a dirty, wet application. Yearly maintenance and repair costs of turbo-compressors rise steeply when they handle moisture-laden gas mixtures. Although elaborate precautions may be taken to prevent slugs of water from entering turbo-compressor inlets, such accidents do occur, and they cause catastrophic failures. Most engineers avoid recommending turbo-compressors for this application, and Gardner Denver Nash does not supply them for condenser gas extraction systems.

\section{How the components are combined}

First costs, operating costs, geothermal field management and environmental considerations all influence the selection of components and the ways they are combined to form a system.

In most cases, each main condenser will be served by two or more parallel trains of components to provide operating flexibility and redundancy. The sum of their capacities usually equals or slightly exceeds anticipated operating requirements. In the following discussions and illustrations, a single train of components is treated as the basic system, even though it may be only one of several trains serving a single condenser.

Whether the choice is made to use direct-contact barometric condensers or shell-and-tube surface condensers, the selection of other components can be made independently. As long as condenser fouling can be managed satisfactorily, both types perform equally well. Effluent control requirements determine the choice between the two. The extra cost of surface condensers must be justified by the value placed on a segregated cooling water system.

In the past, an all-jet system was the classic, most widely used condenser gas extraction system for geothermal power plants. Each of the three ejector stages is followed by a condenser, as more moisture can be condensed at each succeeding higher pressure. At an installation where the main condenser does not remove enough of the condensable vapor, the gas extraction system often includes a pre-condenser or gas cooler that reduces the vapor load to the first-stage ejector.

Over the last fifteen years, the Gardner Denver Nash "hybrid system" has gained acceptance as a more popular choice for gas extraction systems. These systems use far less energy than all-ejector systems and will help extend the life of each well. With a Gardner Denver Nash vacuum pump in place of the last stage ejector in a three-stage system, the steam savings pay for electric power to run the pump and leave a substantial extra margin of overall energy gain.
Still greater operating cost savings can be achieved by going to a two-stage hybrid system, with one initial ejector stage, and a large vacuum pump.

When you evaluate costs on a short-term basis, an all-ejector system invariably appears to be the best choice because of its low initial cost. However, when you calculate the sum of initial investment plus operating costs over longer and longer terms, including Gardner Denver Nash vacuum pumps in the system shows up as a better and better choice, delivering a high rate of return on the additional capital invested.

Another benefit that the hybrid systems afford is operating flexibility. If available steam pressure or other design parameters should change as the field matures, the inherent operating characteristic of liquid-ring vacuum pumps allows them to compensate for the changes. A hybrid system, thus, will adapt itself with fewer equipment modifications over the years.

\section{Evaluating the tradeoffs}

Comparisons in the following typical examples show how relative costs and savings of different system choices can be evaluated to form a basis for your informed decisions.

In these cases, we have assumed that direct-contact condensers will be used, and that the main condenser will also be direct-contact. A pre-condenser or gas cooler is therefore included as part of the gas extraction system. Turbine exhaust steam is assumed to contain $14 \%$ moisture. This variable affects the total quantity of cooling water utilized. That water will release dissolved air, which will add to the non-condensable load.

In Case 1, gas load from the main condenser to the gas cooler is assumed to consist of:

Air

Other non-condensables

Steam

$290 \mathrm{kh} / \mathrm{hr}$ $4,040 \mathrm{~kg} / \mathrm{hr}$ $16,057 \mathrm{~kg} / \mathrm{hr}$

Other assumptions:

Turbine exhaust pressure

Drop across main condenser

Drop across gas cooler

Drop in piping and valves

$126.67 \mathrm{mbarA}$

$2.5 \mathrm{mmHg}$

$2.0 \mathrm{mmHg}$

$3.9 \mathrm{mmHg}$

Steam cost

Electric power cost

Operating time

$\$ 4.40 / 1000 \mathrm{~kg}$

$\$ 0.04 / \mathrm{kWhr}$

8,700 hours/year

Each of the three options presented is sized for $50 \%$ of total capacity, so that two identical trains are needed to handle gases drawn from the main condenser. Option $A$ is an allejector system. Option B is a three-stage hybrid system. 
Option C is a two-stage hybrid system.

In Case 2, gas loading from the main condenser is assumed to consist of:

Air

Other non-condensables

Steam

All other assumptions are the same as those for the first case. The three options are the same as those for the first case, too, except that each train is sized for $25 \%$ capacity.

\section{The low-cost option}

In each of these two typical cases, Option A, the all-jet system, shows an attractively low initial investment. However, the annual operating costs are far higher than either of the other two cases.

\section{The balanced option}

Option B, the three-stage hybrid system, balances operating costs savings against initial investment.

\section{The low operating cost option}

Option $C_{1}$ the two-stage hybrid system has the lowest operating costs. The higher initial investment to gain this cost reduction, however, extends its payoff time considerably.

\section{For Facts and Figures Related to Your Project}

This brief summary of Gardner Denver Nash's engineering approach to geothermal power plant systems is backed up by volumes of technical calculations, operating cost analyses, and comparisons of alternate system choices.

The sheer bulk of this data prevents us from including all of it here. Our experience shows that each customer's systems and needs differ. We will be glad to review with you data that relates to your own project.

Contact the Gardner Denver Nash office nearest you or our Power Division headquarters in Elizabeth, PA:

700 McKeesport Road

Elizabeth, PA 15037-1864 USA

Tel: +14123843610

Fax: +14123844880

nash@gardnerdenver.com 


\section{Costs \& Savings - Case 1}

Option A

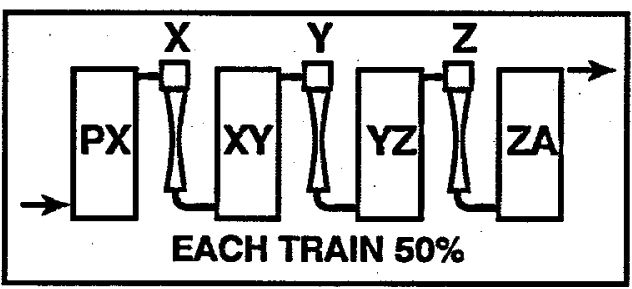

Option B

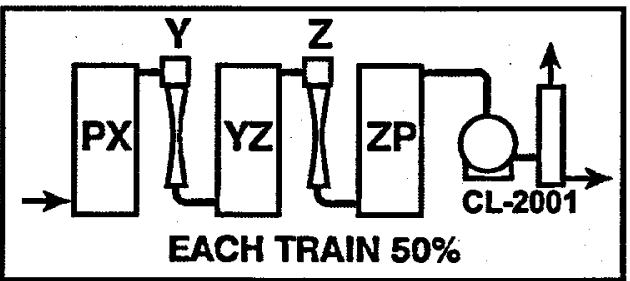

Option C

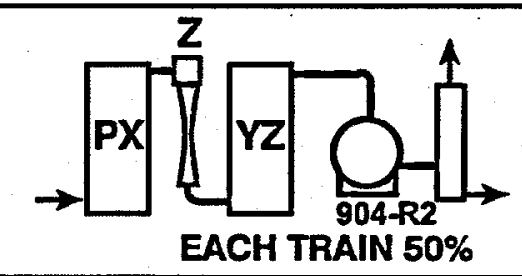

Cooling Water @ 35ㄷ Max.

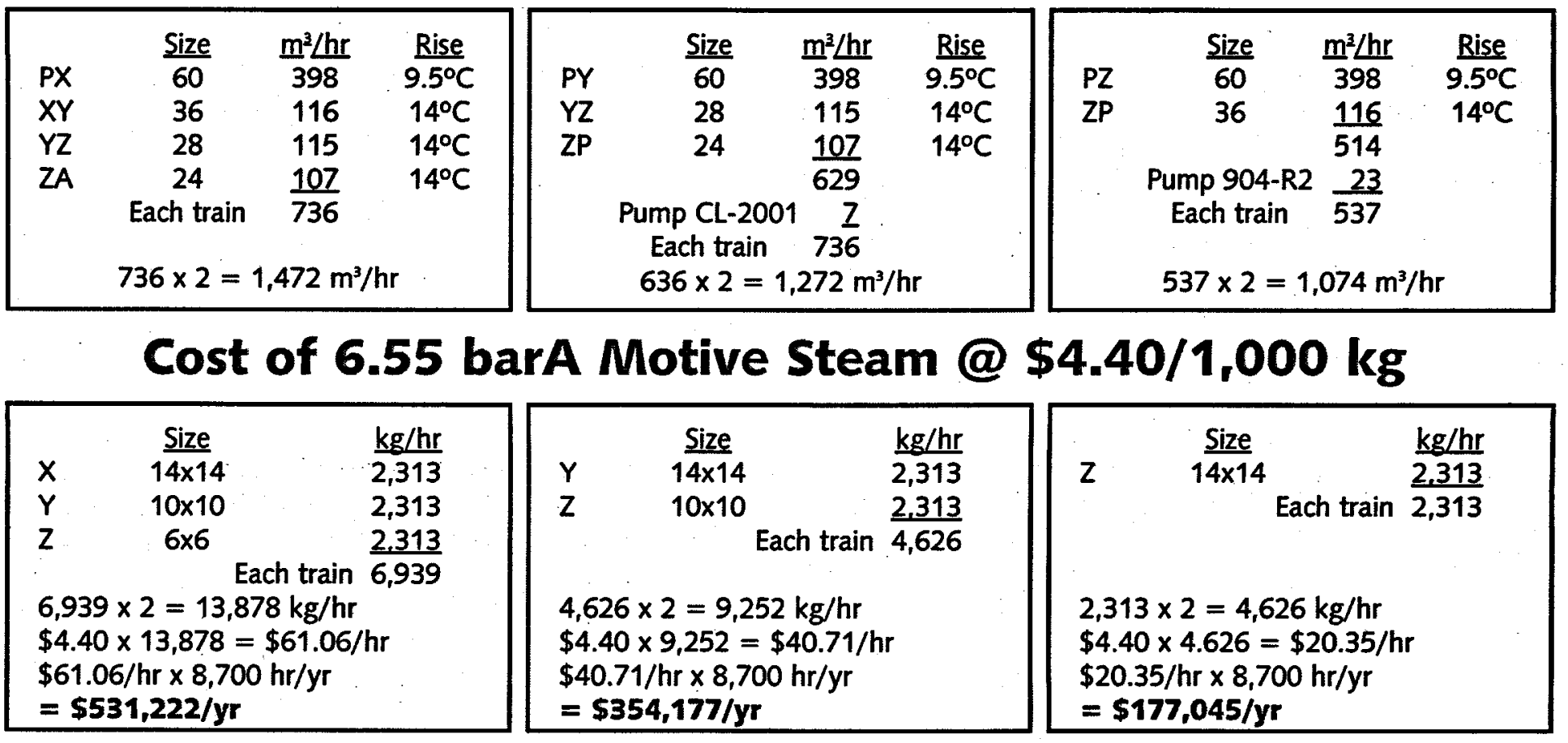

\section{Cost of Electric Power @ \$0.04/kWhr}

$0 \mathrm{~kW}$

$\$ 0$
$60 \mathrm{~kW} \times 2=120 \mathrm{~kW}$

$\$ 0.04 / \mathrm{kWhr} \times 120=\$ 4.80 / \mathrm{hr}$

$\$ 4.80 / \mathrm{hr} \times 8,700 \mathrm{hr} / \mathrm{yr}$

$=\$ 41,760 / \mathrm{yr}$
$174 \mathrm{~kW} \times 2=348 \mathrm{~kW}$

$\$ 0.04 / \mathrm{kWhr} \times 348=\$ 13.92 / \mathrm{hr}$

$\$ 13.92 / \mathrm{hr} \times 8,700 \mathrm{hr} / \mathrm{yr}$

$=\$ 121,104 / y r$

\section{Operating Cost - Steam \& Electric Power}

\section{$\$ 531,222 / y r$ \\ Operating Cost Savings \\ (base)}

\section{$\$ 395,937 / y r$}

Operating Cost Savings $\$ 135,285 / y r$

\section{$\$ 298,149 / y r$}

Operating Cost Savings $\$ 233,073 / \mathbf{y r}$

\section{Capital Cost}

\section{$\$ 250,000$}

Payoff Time: (base)

First Year Cost: \$781,222

\section{$\$ 575,000$}

Payoff Time: 2.4 years

First Year Cost: $\$ 970,937$
$\$ 1,075,000$

Payoff Time: 3.6 years

First Year Cost: \$1,373,149 


\section{Costs \& Savings - Case 2}

Option A

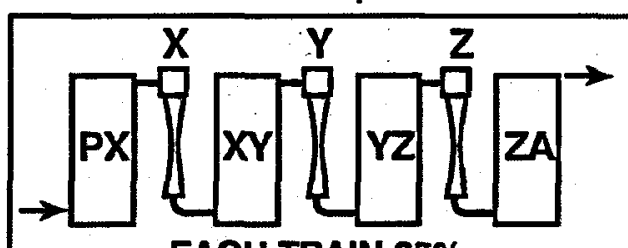

EACH TRAIN 25\%
Option B

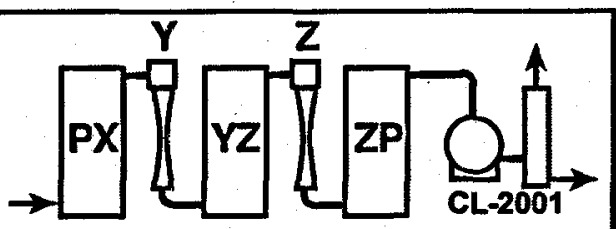

EACH TRAIN 25\%
Option C

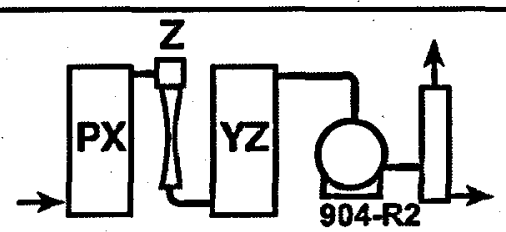

EACH TRAIN 25\%

\section{Cooling Water @ 35ㄷ Max.}

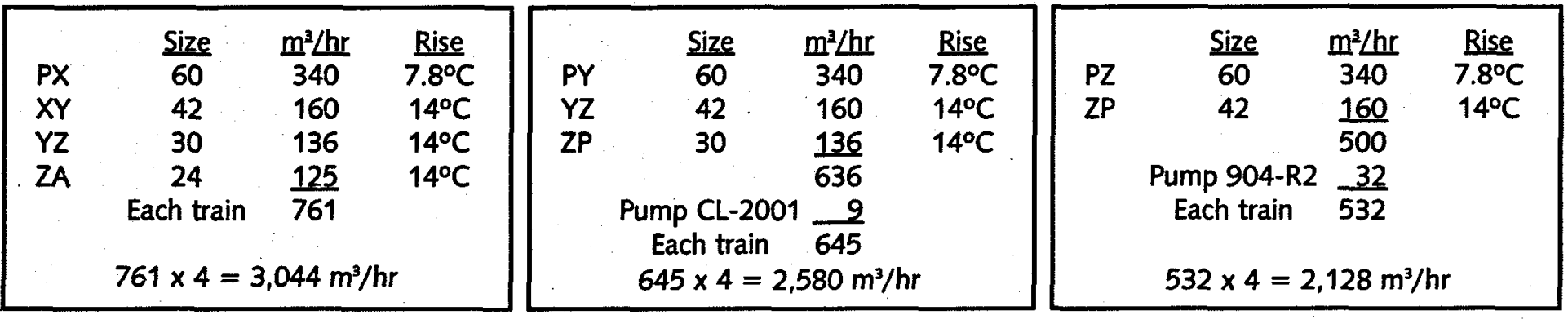

Cost of 6.55 barA Motive Steam @ \$4.40/1,000 kg

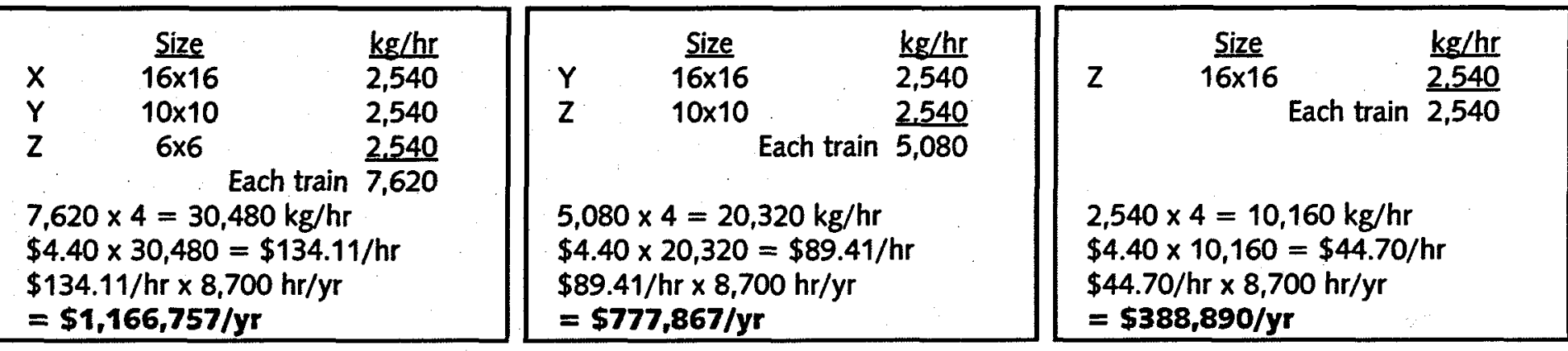

Cost of Electric Power @ \$0.04/kWhr

\begin{tabular}{|c|}
$0 \mathrm{~kW}$ \\
\\
50 \\
\hline
\end{tabular}

$87 \mathrm{~kW} \times 4=348 \mathrm{~kW}$

$\$ 0.04 / \mathrm{kWhr} \times 348=\$ 13.92 / \mathrm{hr}$

$\$ 13.92 / \mathrm{hr} \times 8,700 \mathrm{hr} / \mathrm{yr}$

$=\$ 121,104 / y r$
$259 \mathrm{~kW} \times 4=1,036 \mathrm{~kW}$

$\$ 0.04 / \mathrm{kWhr} \times 1,036=\$ 41.44 / \mathrm{hr}$

$\$ 41.44 / \mathrm{hr} \times 8,700 \mathrm{hr} / \mathrm{yr}$

$=\$ 360,528 / \mathrm{yr}$

\section{Operating Cost - Steam \& Electric Power}

$\$ 1,166,757 / y r$

Operating Cost Savings

(base)
$\$ 898,971 / y r$

Operating Cost Savings $\$ 267,786 / y r$
$\$ 749,418 / y r$

Operating Cost Savings

$\$ 417,339 / y r$

\section{Capital Cost}

$\$ 500,000$

Payoff Time: (base)

First Year Cost: \$1,666,757

\section{$\$ 1,175,000$}

Payoff Time: 2.5 years

First Year Cost: \$2,073,971

\section{$\$ 2,150,000$}

Payoff Time: 4.0 years

First Year Cost: $\$ \mathbf{2 , 8 9 9 , 4 1 8}$ 


\section{Our History of Successful Installations}

\section{CUSTOMER}

\section{USER/Plant}

NCPA California Geysers

PSNM-BACA Ejectors

Now Installed At CFE-Los Azuferes, Mexico

3. SMUD

SMUD Geo. \#1

California Geysers

\begin{tabular}{ll}
\hline 1. & Ecolaire \\
\hline 2. & Ecolaire \\
\hline
\end{tabular}

YEAR SOLD

106

1979

1980

72

1981

1982

State of California

55

40

1982

OXY Geothermal (Santa Fe)

California Geysers

6. Ecolaire

Utah P\&L Bundell 1

Roosevelt Hot Springs

7. DeLaval

Heber Geothermal California

California Geysers

State of California, South Geyser

Yang Ba Jine Geothermal

Tibet

11. DeLaval

Heber-Binary

Beowawe Geothermal Elko Nevada

12. Beowawe Geothermal

Bottle Rock California Geysers

Upgrade of Item 4

Salton Sea Unit \#3

California

Oxbow Geothermal

Nevada

15. FUJI Electric

Bear Canyon

California Geysers

GEM Unit \#2 East Mesa California

18

1988

17. $\mathrm{MHI}$

GEM Unit \#3

East Mesa California

18.5

1988

18. $\mathrm{MHI}$

Mission Power - Navy 1

COSO Hot Springs California

19. Ecolaire

Mission Power BLM East COSO Hot Springs California

20. Ecolaire

Mission Power BLM WEST

COSO Hot Springs California

21. Ecolaire

Mission Power Navy II

COSO Hot Springs California

23. Dow Engineering

Magma Power

$2 \times 25$

1988

$2 \times 24$

1988

28

1988

$3 \times 25$

1988

22. Ecolaire

$?$ 
We include a listing of our recent projects in this section. If you would like to have more information about the choices involved with these jobs or about their technical features, we will be glad to describe them to you.

\begin{tabular}{|c|c|c|c|}
\hline NC Capacity & $\begin{array}{l}\text { SUCTION } \\
\text { PPH }\end{array}$ & $\begin{array}{l}\text { CONFIGURATION } \\
\text { Pressure In.HGA }\end{array}$ & COMMENTS \\
\hline 1,830 & 1.76 & ECEC & $60 / 40$ \\
\hline 28,010 & 3.00 & EBEB & $\begin{array}{l}4-25 \% \text { - 1st Stages } \\
2-50 \% \text { - 2nd Stages }\end{array}$ \\
\hline 3,900 & 1.16 & ECEC (VP) & $\begin{array}{l}3-50 \% \text { - 1st Stages } \\
2-100 \% \text { - 2nd Stages } \\
3-50 \% \text { - 3rd Stages } \\
\text { NASH CL-3003 VP }\end{array}$ \\
\hline 9,022 & 3.32 & ECEC & $33 a \%$ Elements \\
\hline 13,513 & 2.90 & ECEC & $\begin{array}{l}2-50 \% \text { - 1st Stages } \\
1-100 \% \text { - 2nd Stages }\end{array}$ \\
\hline 12,130 & 2.61 & ECEC & $75 / 50 / 25$ Elements \\
\hline 642 & 2.48 & $E C(V P)$ & $\begin{array}{l}3-50 \% \text { Trains } \\
\text { NASH CL-402 VP }\end{array}$ \\
\hline 20,492 & 3.40 & EBEB & $\begin{array}{l}2-50 \% \text { - 1st Stages } \\
1-100 \% \text { - 2nd Stages }\end{array}$ \\
\hline 2,215 & 1.85 & ECEC & 3-50\% Elements \\
\hline 730 & 2.25 & $\mathrm{BE}$ & $\begin{array}{l}\text { Water Operated Eductor } \\
\text { w/114" Turbine Condenser }\end{array}$ \\
\hline 3,157 & 3.0 & ECEC & $\begin{array}{l}\text { To be used in conjunction with } \\
\text { Number } 7\end{array}$ \\
\hline $3164 / 2949$ & $0.8-1.25$ & EBEB (VP) & $\begin{array}{l}\text { Two stage Hybrid with A 1st } \\
\text { Stage Ejector and CL-1003 VP }\end{array}$ \\
\hline 23,417 & 3.32 & C & After-Condenser \\
\hline $\begin{array}{l}80 \% 4581 \\
60 \% 3666\end{array}$ & $1.26 / 1.85$ & ECECEC (LP/HP) & $\begin{array}{l}80 / 60 / 40 \% \text { Trains. Dual 1st Stage } \\
\text { for } 2 \text { Pressure Main Condenser Side } \\
\text { with Pre-Cooler on HP Side }\end{array}$ \\
\hline 10,398 & $0.55 / 1.005$ & EBEBE & $\begin{array}{l}\text { Three } 50 \% \text { Element Dual First } \\
\text { Stages for } 2 \text { Pressure Main Condenser }\end{array}$ \\
\hline 2,434 & 1.36 & ECEC & $\begin{array}{l}\text { Four Duplicate Units Three Element } \\
40 / 35 / 25 \% \text { See \#41 } \\
\text { Upgraded in } 1992\end{array}$ \\
\hline 3,300 & 2.6 & EBEBVP & $\begin{array}{l}\text { Two } 100 \% \text { First and Second Stage } \\
\text { Ejector with } 200 \% \text { Barometric Inter- } \\
\text { Condensers and Two } 100 \% \\
\text { CL-2002 VP }\end{array}$ \\
\hline 3,300 & 2.6 & EBEBVP & $\begin{array}{l}\text { Two } 100 \% \text { First and Second Stage } \\
\text { Ejector with } 200 \% \text { Barometric Inter- } \\
\text { Condensers and Two } 100 \% \\
\text { CL-2002 VP }\end{array}$ \\
\hline 10,000 & 2.6 & ECEC & $\begin{array}{l}\text { Two } 100 \% \text { Elements } \\
2 \text { Units }\end{array}$ \\
\hline 8,800 & 2.1 & ECEC & $\begin{array}{l}\text { Two } 100 \% \text { Elements } \\
2 \text { Units }\end{array}$ \\
\hline 14,800 & 2.1 & ECEC & $\begin{array}{l}\text { Two } 100 \% \text { Elements } \\
1 \text { Unit }\end{array}$ \\
\hline 10,000 & 2.1 & ECEC & $\begin{array}{l}\text { Two } 100 \% \text { Elements } \\
3 \text { Units }\end{array}$ \\
\hline 215 & 1.0 & $\begin{aligned} & E C(V P) \\
& \sim 9 \sim\end{aligned}$ & $2-100 \%$ 1st Stages, $10 \times 10$ \\
\hline
\end{tabular}


24. Ben Holt Company

25. Santa Fe Geothermal

26. Toshiba

27. Toshiba

28. Toshiba

29. Toshiba

30. Electricorp

31. Electricorp

32. Electricorp

33. Electricorp

34. $\mathrm{MHI}$
Utah Municipal Power Unit \#2 Cove Fort

Santa Fe Geothermal (OXY)

California Geysers

Upgrade of Item 5

National Power Corp.

of The Philippines

Tiwi Plant Unit 1

National Power Corp.

of The Philippines

Tiwi Plant Unit 2

of The Philippines

Tiwi Plant Unit 5

National Power Corp.

of The Philippines

Tiwi Plant Unit 6

Electricorp Waireki

"A". Unit G7

New Zealand

Electricorp Waireki

"A" Unit G8

New Zealand

Electricorp Waireki

"A" Unit G9

New Zealand

Electricorp Waireki

"A" Unit G10

New Zealand

National Power Corp.

of The Philippines

Cawayan Station
National Power Corp.

8

40

55

1991

55

1991

55

1991

55

1991

11.2

1991

11.2

1991

11.2

1991

11.2

1991

20

1992

National Power Corp.

20

1992

of The Philippines

Botong Station

National Power Corp.

20

1992

of The Philippines

Nasuji Station

National Power Corp.

20

1992

of The Philippines

Okoy Station

National Power Corp.

20

1992

of The Philippines

Sogongon I

National Power Corp.

39. FUJI

of The Philippines

Sogongon II 


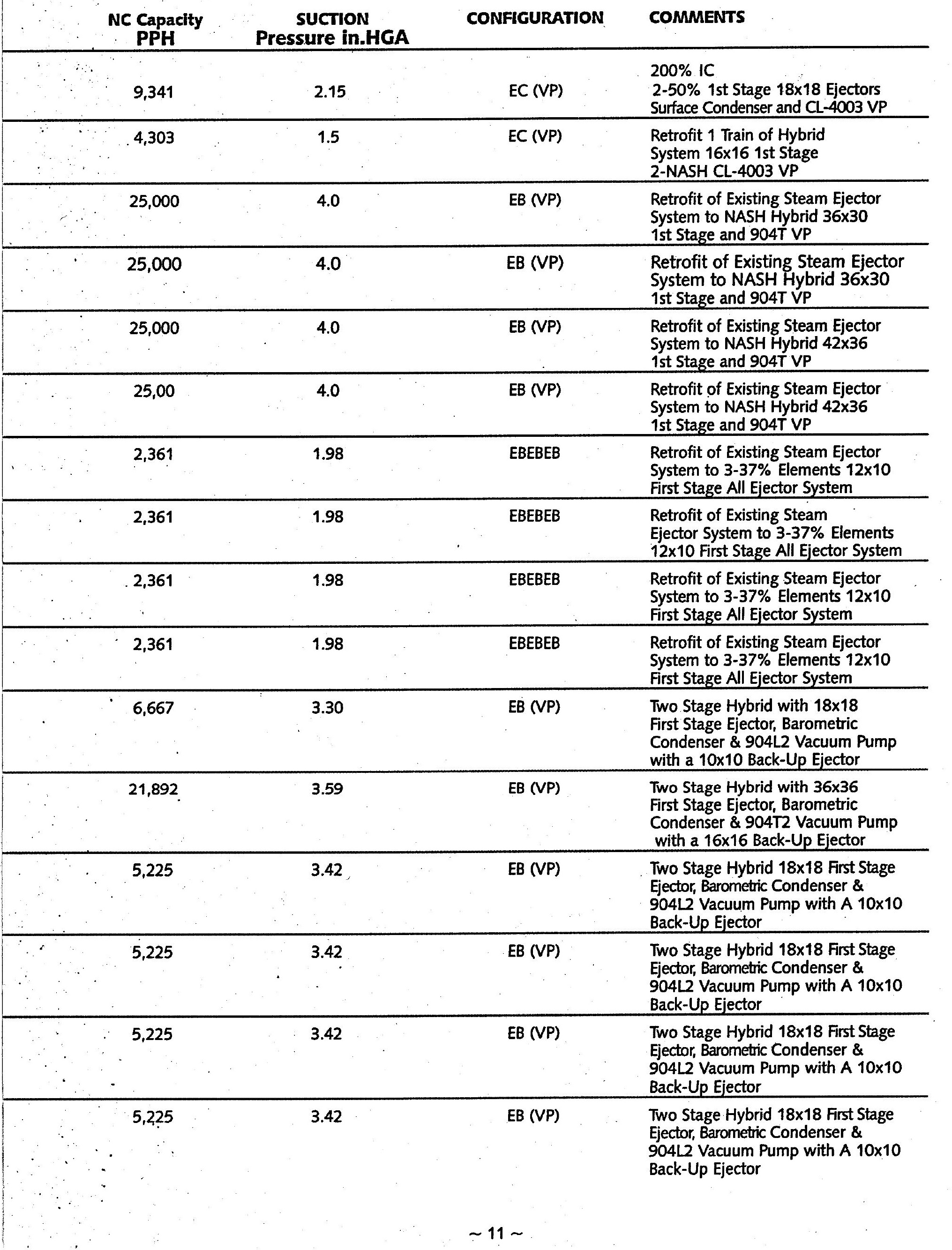


40. Calpine Corp.

Upgrade \#16

41. Calpine Corp.

42. $\mathrm{MHI}$
Bear Canyon

California Geysers

Westford Flats

California Geysers, Upgrade Existing Unit

PLN/Darajat

Indonesia

NPC/MAKBAN

Philippines

NPC/MAKBAN

Philippines

NPC/MAKBAN

Philippines
20

20

55

20

1993

45. MHI

46. $\mathrm{MHI}$
NPC/MAKBAN

Philippines

Philippines

20

1993

BLM East - Upgrade \#20

$2 \times 25$

1994
(COSO)

47. California Energy (COSO)

48. California Energy (COSO)
BLM West - Upgrade \#21

USA
25

1994

$3 \times 25$

1994

Navy 1 - Upgrade \#19

USA
Navy 2 - Upgrade \#22

USA

\section{nergy}

USA \\ 50. Californ
(COSO)}

(.

\section{PG\&E}

52. NCPA

Unit 17

Navy 2 - Upgrade \#22/50

$3 \times 25$

82

1994

$53 \quad 1994$
53. California Energy (COSO)

54. PG\&E

Unit 13

110

1995

55. MHI

(2)

55. $\mathrm{MHI}$
MT APO
Philippines

48.7

1995

56. Northern California Power Agency

NCPA Plant 1 - Unit 1

Geysers

57. Fluor Daniel/UNOCAL

SALAK - Indonesia 
NC Capacity

SUCTION

PPH
Pressure In.HGA

$\begin{array}{llll}2,434 & 1.36 \quad \text { EC (VP) }\end{array}$

$2,434 \quad 1.36$

5,188

3.72

3.3

EB (VP)
CONFIGURATION
3.3

3.3

3.3

1,521

1,521

1,521

32,000

24,000

24,000

2.6

2.1

ES (VP) COMP.

2.6

ES (VP) COMP

EB (VP)

$E B(V P)$

$E B(V P)$

ES (VP) COMP

2.6

ES (VP) COMP

41,000
COMMENTS

Two SC-7 Vacuum Pumps to Replace $40 \%$ Second Stage Ejectors

Two SC-7 Vacuum PUMPS to Replace $40 \%$ Second Stage Ejectors

Two Stage Hybrid with Two 100\% First Stage $24 \times 24$ Ejectors with Barometric Condensers Two $50 \%$ 904P-3 VP 16×16 Back-Up Ejector

Two Stage Hybrid with $14 \times 14$ First Stage Ejector, Barometric Condenser \& CL-2002 Vacuum Pump with a 8x8 Back-Up Ejector

Two Stage Hybrid with $14 \times 14$ First Stage Ejector, Barometric Condenser \& CL-2002 Vacuum Pump with a 8x8 Back-Up Ejector

Two Stage Hybrid with 14x14 First Stage Ejector, Barometric Condenser \& CL-2002 Vacuum Pump with a $8 \times 8$ Back-Up Ejector

Two Stage Hybrid with $14 \times 14$ First Stage Ejector, Barometric Condenser \& CL-2002 Vacuum Pump with a 8x8 Back-Up Ejector

Upgrade of Existing All Ejector System to A Hybrid. Added Two (2) 904T (VP) Discharging into a 904R Compressor

Upgrade of Existing All Ejector System to A Hybrid. Added 904R and $P(V P)$, Dlscharging into a 904L1 Compressor

Upgrade of Existing All Ejector System to A Hybrid. Added 904T and $P(V P)$, Discharging into a 904L1 Compressor

Upgrade of Existing All Ejector System to A Hybrid. Added Two (2) $904 \mathrm{~T}$ and One (1) 904P Discharging into a 904R1 Compressor Revamp Existing 2 Stage to 3 Stage

Revamp Existing 2 Stage Jet System to 3 Stage Hybrid (SC-7)

Replace Existing 904P2 with 904T2 Upgrade Capacity

\begin{tabular}{lll}
\hline 48,000 & 2.6 & VP \\
\hline 2,624 & 2.2 & ESES (VP) \\
\hline 9,000 & 2.3 & EBEB (VP)
\end{tabular}

1740

1.76

ESES (VP)

Revamp 2 Stage Jet to 3 Stage Hybrid (SC-11)

$50 \%$ Ejector Elements $100 \%$ Liquid Ring Vacuum Pump with Back-Up Ejector Stage

Revamp Existing 2 Stage Jet System to 3 Stage Hybrid (SC-7) 
58. Mercury Geothermal

Pohipi - New Zealand

1996

59. Yankee Caithness

Steamboat Geothermal Plant

15

1996

Reno, NV

60. Oxbow Geothermal

Dixie Valley

50

1996

Upgrade of \#15

61. GILBERT/CBE

Dieng Unit 1

Indonesia

1996

Berlin Geothermal

$2 \times 27.5$

1997

62. SAI Geothermal

El Salvador

63. FUJ

Svrtsengi, Iceland

30

1997

64. Stone \& Webster

Darajat II, Indonesia

70

1997

65. Stone \& Webster

Darajat III, Indonesia

70

1997

66. FUII

Wayang Windu

110

1997

67. FUII

Wayang Windu

110

1997

68. FUJI

Hachijyo

3.3

1997

69. MHI

Mindanao II

48.25

1997

$70 \mathrm{MHI}$

Nesjavellir, Iceland Unit 1

30

1997

$71 \mathrm{MHI}$

Nesjavellir, Iceland Unit 2

30

1997

72 CAL Energy

Salton Sea, Unit 2

$73 \mathrm{MHI}$

Miravalles III

27.5

1998

Costa Rica

$74 \quad \mathrm{MHI}$

Cerro Prieto IV Units 1-4

$4 \times 25$

1998

Mexico

75 NCPA (Northern

Geysers \#1

55

1998

California Power Agency)

76 American Caribbean Intl.

Ahuachapan

1999

El Salvador

77 Stone \& Webster

Region II Vulcan

34.5

1999

78 Kingston Morrison

TIWI Philippines

85

1999

79 Alstom

Tres Virgenes

10

1999

Mexico

80 Stone \& Webster

Salton Sea, Unit 5

47.5

1999

Botoming

1999

Philippines

2000

$82 \mathrm{MHI}$

Nesjavellir, Iceland

2000

$83 \mathrm{MHI}$

Olkaria Kenya

2001

84 Alstom

Geysers Units 5 \& 6

2001

Los Azufres Units 13-16

25

Mexico 
NC Capacity

PPH
SUCTION

Pressure in.HGA
CONFIGURATION

2.87

2.0

$.55 / 1.0$

\section{0}

2.55

2.66

1.6

1.6

2.98

2.98

16550

1760

7927

3934

3934

5637

11592

3549

2.36

ES (VP)

$E B(V P)$

EBEB (VP)

EBEB

EBEB

ECVP

EBEBVP

EBEBVP

EBEBVP

EBEBVP

EBEB

EBEBVP

VP

VP

ES

EBVP

3

EBVP

ESESES

EBVP

EBVP

EBVP

EBVP

EBEB

2295

2.24
ECVP

VP

EBVP

EBVP

ECVP

\section{COMMENTS}

(904R2) Pumps

4-25\% 1st Stages, 2-IC, (904L2) Includes Back-Up Ejectors/AC

Revamp Existing 2 Stage Ejector System to Hybrid (904L2)

Replace 3rd Stage Jets with SC-11 LRVP

$33 a \%$ Elements

2 Trains per Unit

$2-50 \%$ Hybrid Trains

$1-50 \%$ Ejector Train

$2-75 \%$ Trains

$2-75 \%$ Trains

$2-50 \%$ Hybrid Trains

1-50\% Ejector Train

$2-50 \%$ Hybrid Trains

$1-50 \%$ Ejector Train

$100 \%$ Ejector Train

$60 / 40 \%$ Ejectors / 100\% VP

$2 \times 505$ Vacuum Pump

$2 \times 505$ Vacuum Pump

Back-Up Second Stage Ejector

$3 \times 50 \% 15 T$ Stage Ejectors

$2 \times 50 \%$ Vacuum Pumps

$50 \%$ Back-Up Ejector

2/012-3-0(SS)

018-2-OBP
$100 \%$ Hybrid Train W

Reinjection Compressor

$2 \times 50 \%$ Vacuum Pumps

$3 \times 50 \%$ Hybrid Trains per Unit 


\section{Upgrades \& Service}

If your existing geothermal plant is more than six or seven years old, it is very likely that its operation can be improved substantially by upgrading its condenser gas extraction systems. It is expected that components are susceptible to erosion, corrosion or damage in other mechanical ways. Geothermal plants, however, are candidates for upgrading for reasons not found in many other industries.

With the life span and output of a plant intimately associated with the condition and output of the steam field, operating conditions may change dramatically over time. The question then is "How to provide optimum performance within economic boundaries?"

Here at Gardner Denver Nash, we have been involved with the design of gas extraction systems since 1974. We are very familiar with the problems noted above, having designed and built both new and upgraded systems.

Four major areas for evaluation in an existing plant will include:

- Increased non-condensable gas flow.

- Declining steam field pressure.

- System flexibility.

- Economics.

We offer a service that will identify the impact of each of these items on your operations. By conducting a complete system survey, with no plant downtime, we can analyze the current level of performance and make recommendations for both short and long-term modifications. A few examples of our work include:

- Modifying systems for increased non-condensable gas flow (California Energy - COSO Area)

- Re-nozzling steam ejectors for declining steam pressures (Northern California Power Agency - Geysers Area)
- Converting an all steam jet system to a hybrid system by the addition of a vacuum pump to extend well life (Santa Fe Geothermal - Geysers Area)

- Redesigning the gas extraction system to dramatically reduce steam consumption by the first and second stage ejectors (Electricorp - Wairakei Area, New Zealand)

- Our vacuum system expertise and our long relationship with Geothermal Power Generation can result in significantly increased profits at your plant.

- Again, please call the Gardner Denver Nash office nearest you for more information.

\section{APPENDIX}

This document contains schematic representations and photographs of various systems supplied by Gardner Denver Nash. We will be happy to discuss any of these designs and how they can best serve your needs. Contact the Gardner Denver Nash office nearest you or our Power Division headquarters in Elizabeth, PA:

\author{
700 McKeesport Road \\ Elizabeth, PA 15037-1864 USA \\ Tel: +14123843610 \\ Fax: +14123844880 \\ nash@gardnerdenver.com
}




\section{Three Stage Ejector System}
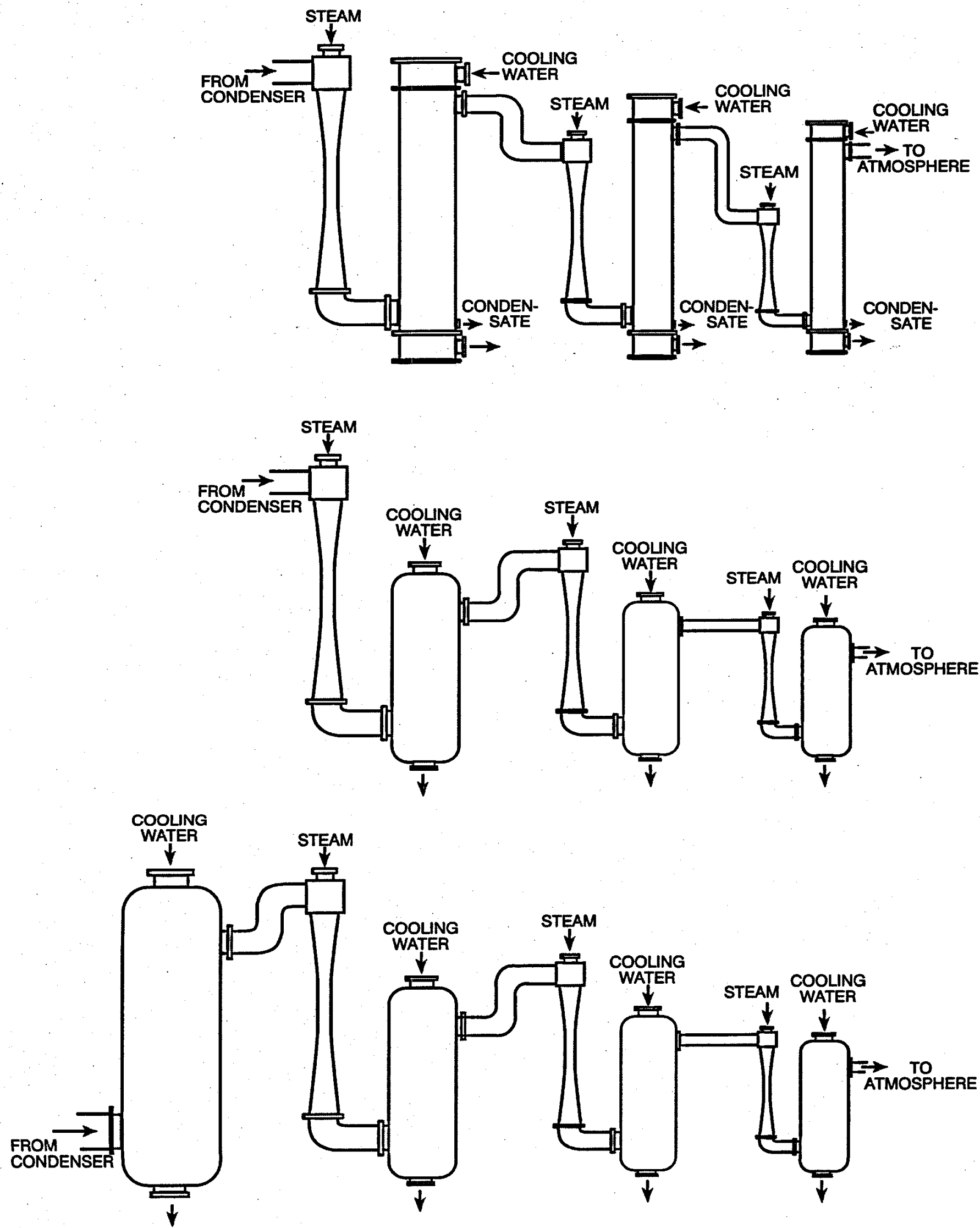

Typical component arrangements for a three stage all-ejector system. At the top is a system with surface condensers. The middle system has direct-contact condensers. On the bottom, a direct-contact pre-condenser or gas cooler precedes the first ejector stage. 


\section{Three Stage Hybrid System}
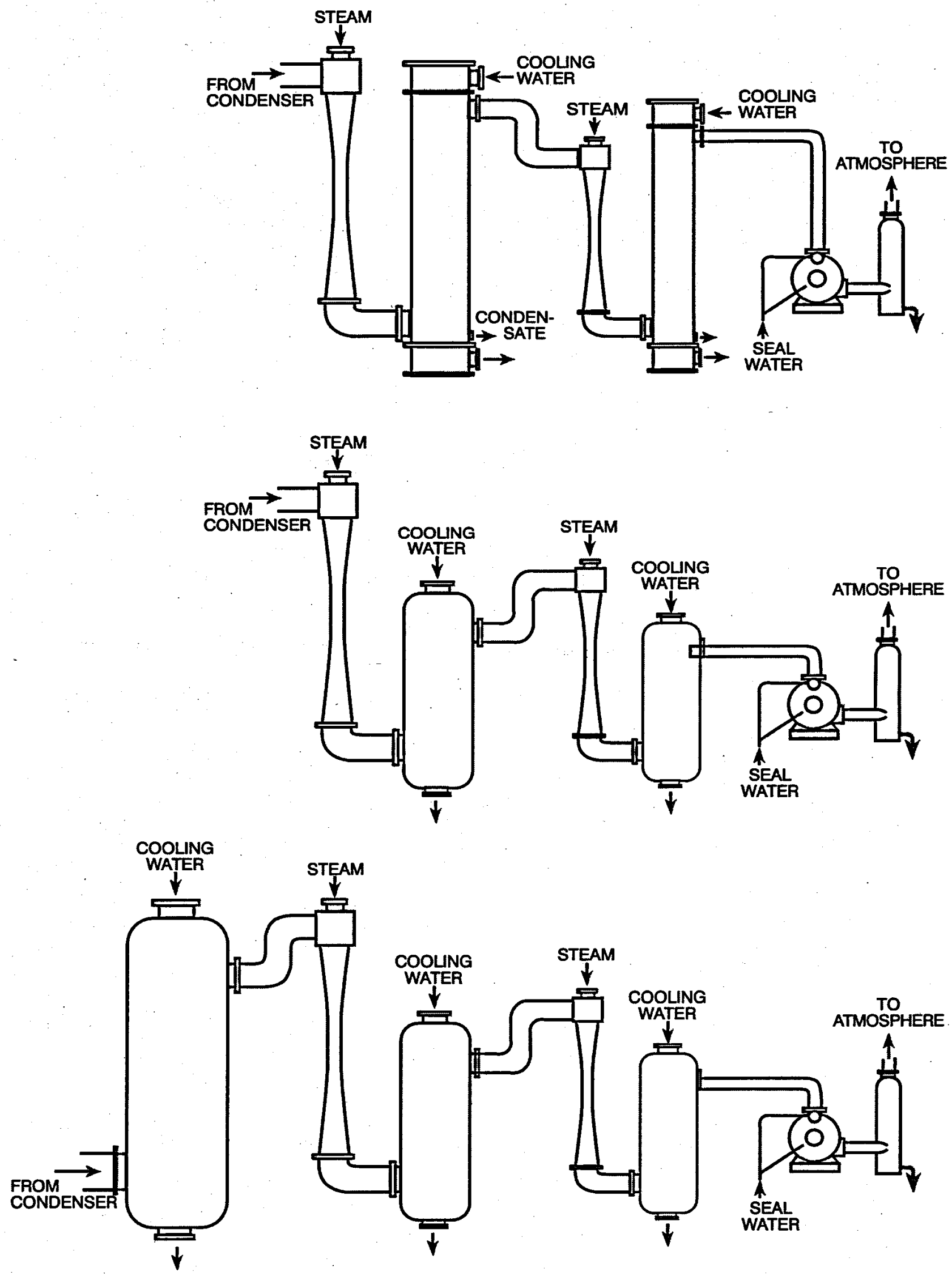

In these three stage hybrid systems, the last stage ejector and its condenser are replaced by a NASH liquid ring vacuum pump. 


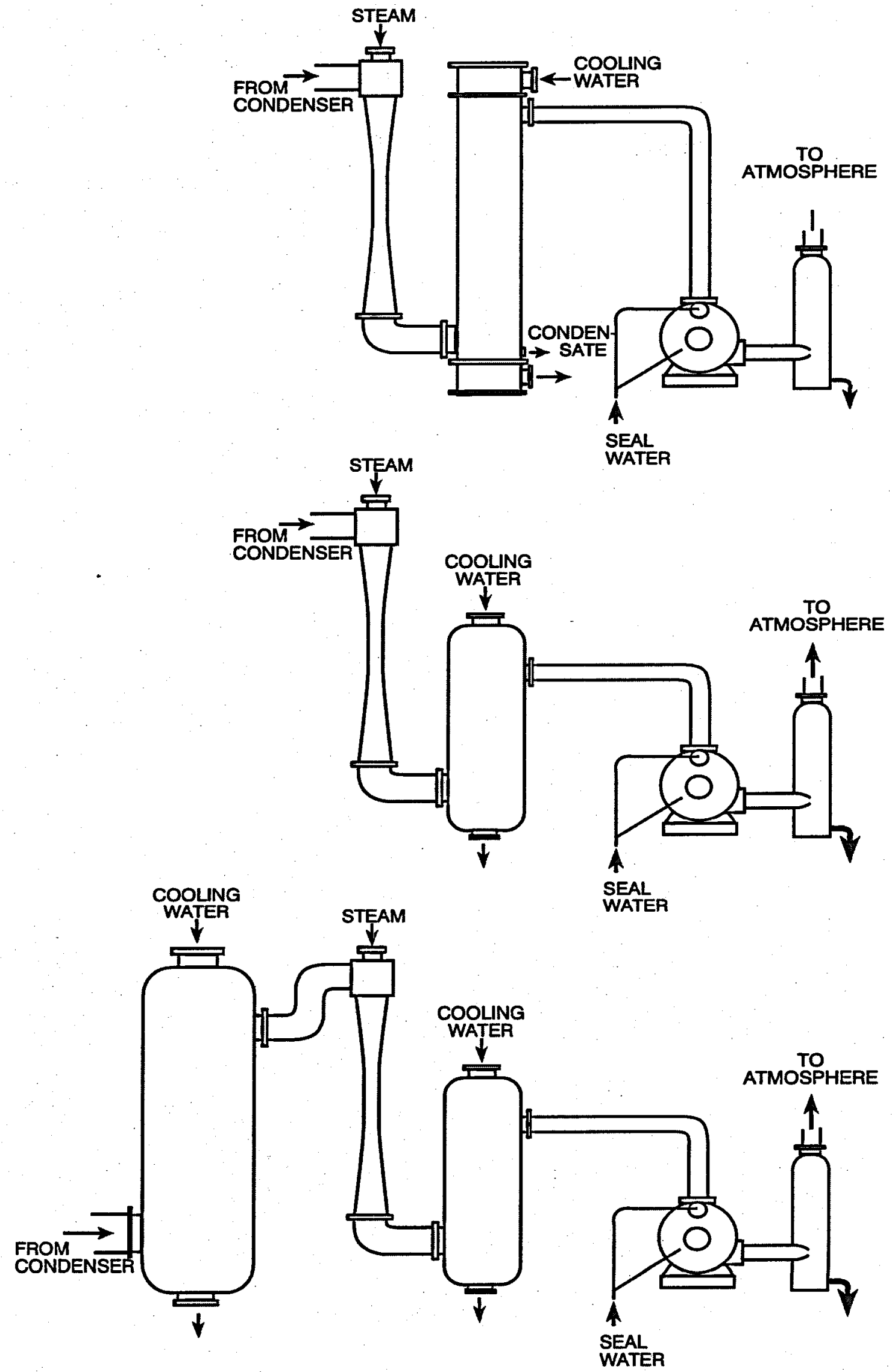

These are two stage hybrid systems. The liquid ring vacuum pump operates at a lower interstage pressure to do more of the work of gas removal than it would in a three stage system. 


\section{Two Stage Hybrid System}
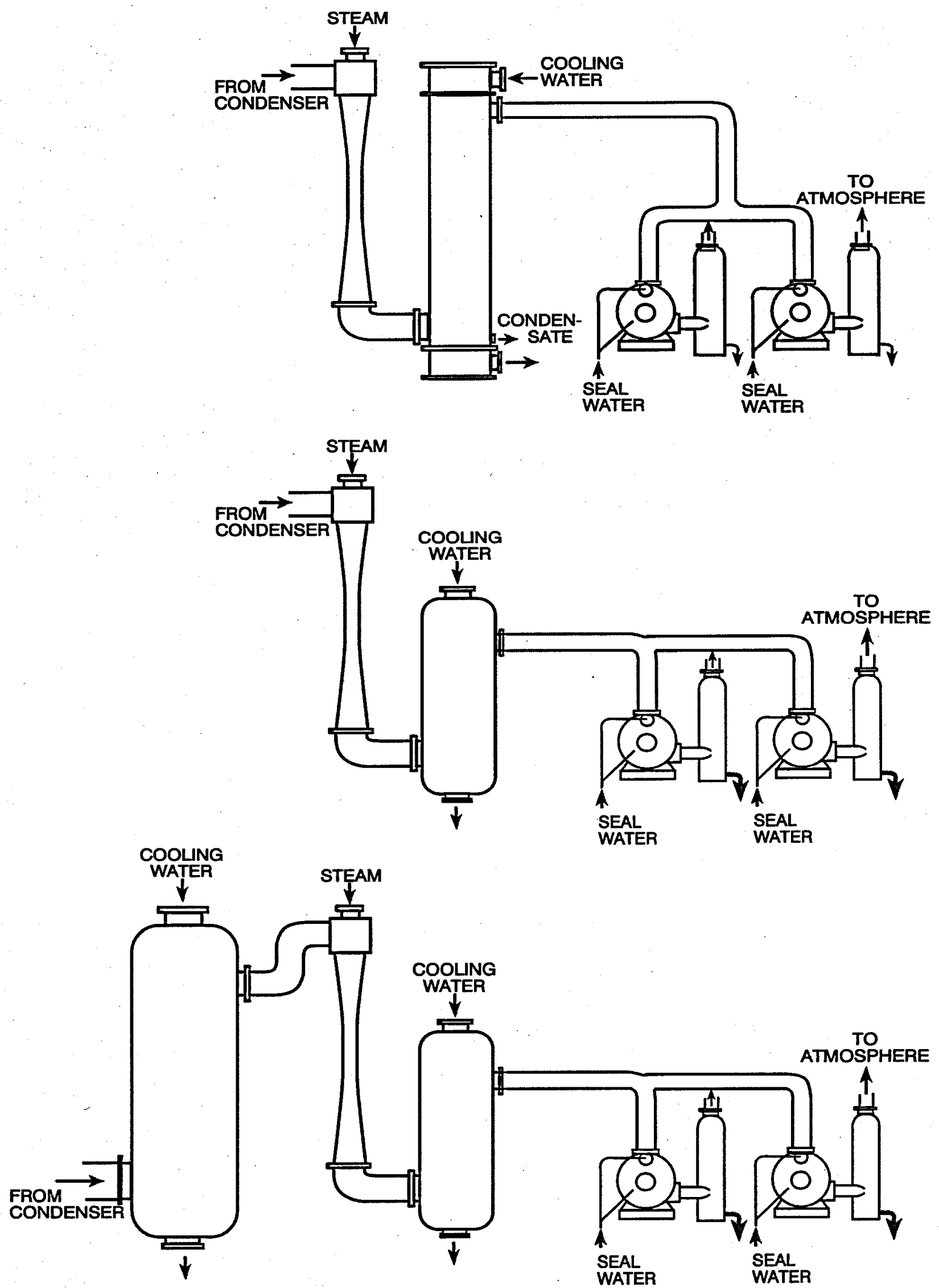

In each of these two stage hybrid systems, two NASH liquid ring vacuum pumps operating in parallel serve as the second stage. 


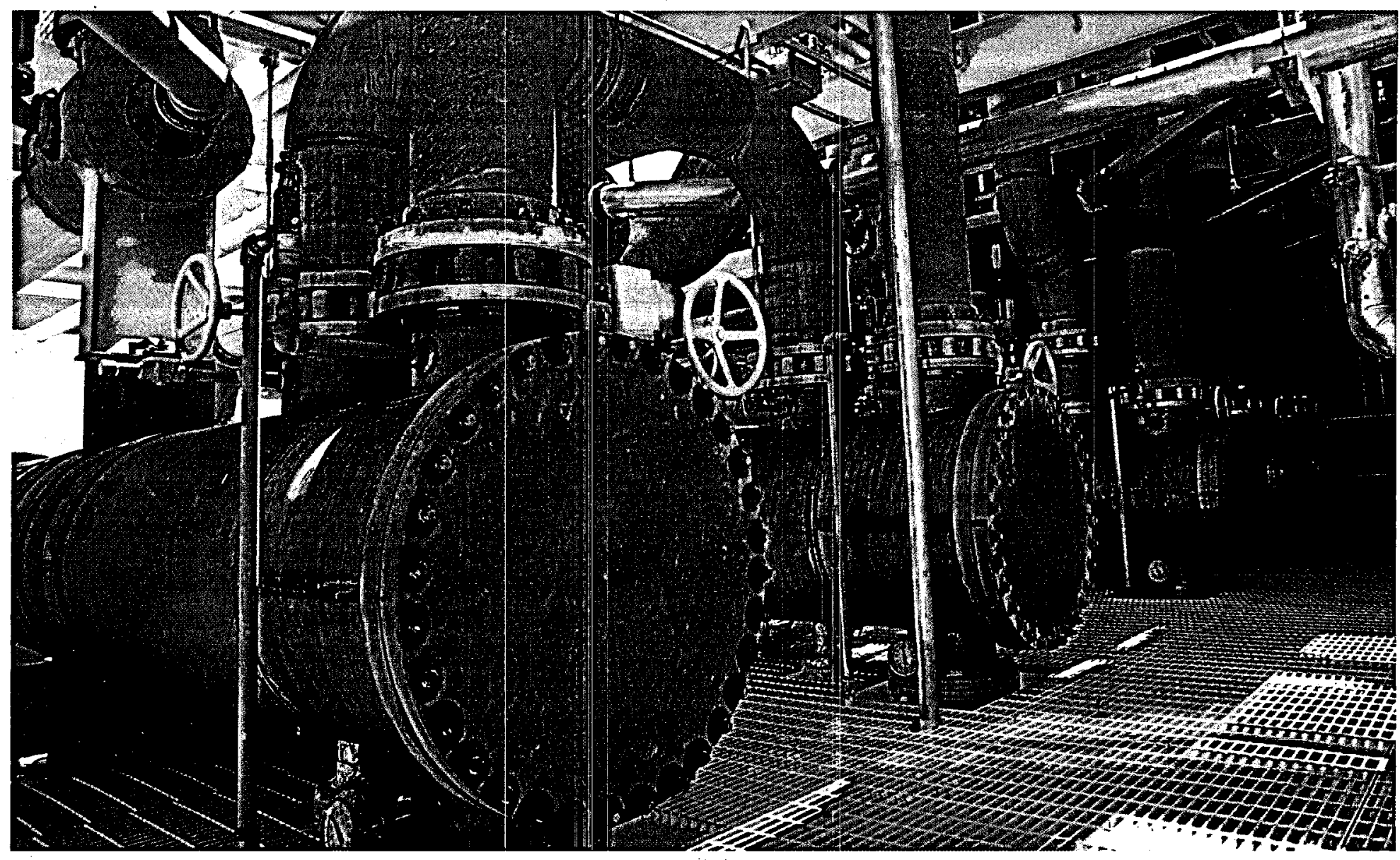

First and Second stage steam jet system by Gardner Denver Nash at SMUD Geothermal Plant

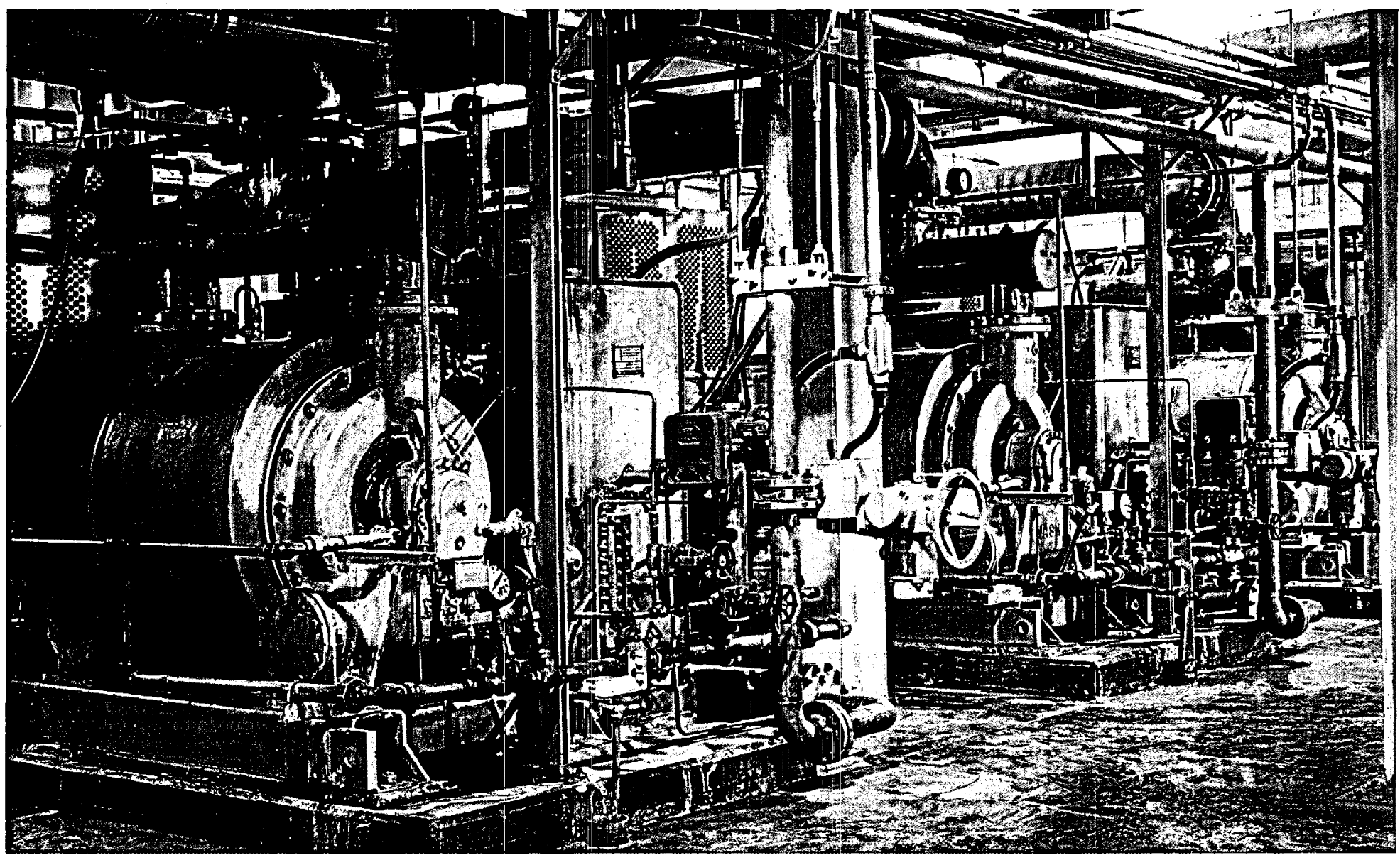

Third stage vacuum pump by Gardner Denver Nash at SMUD Geothermal Plant 


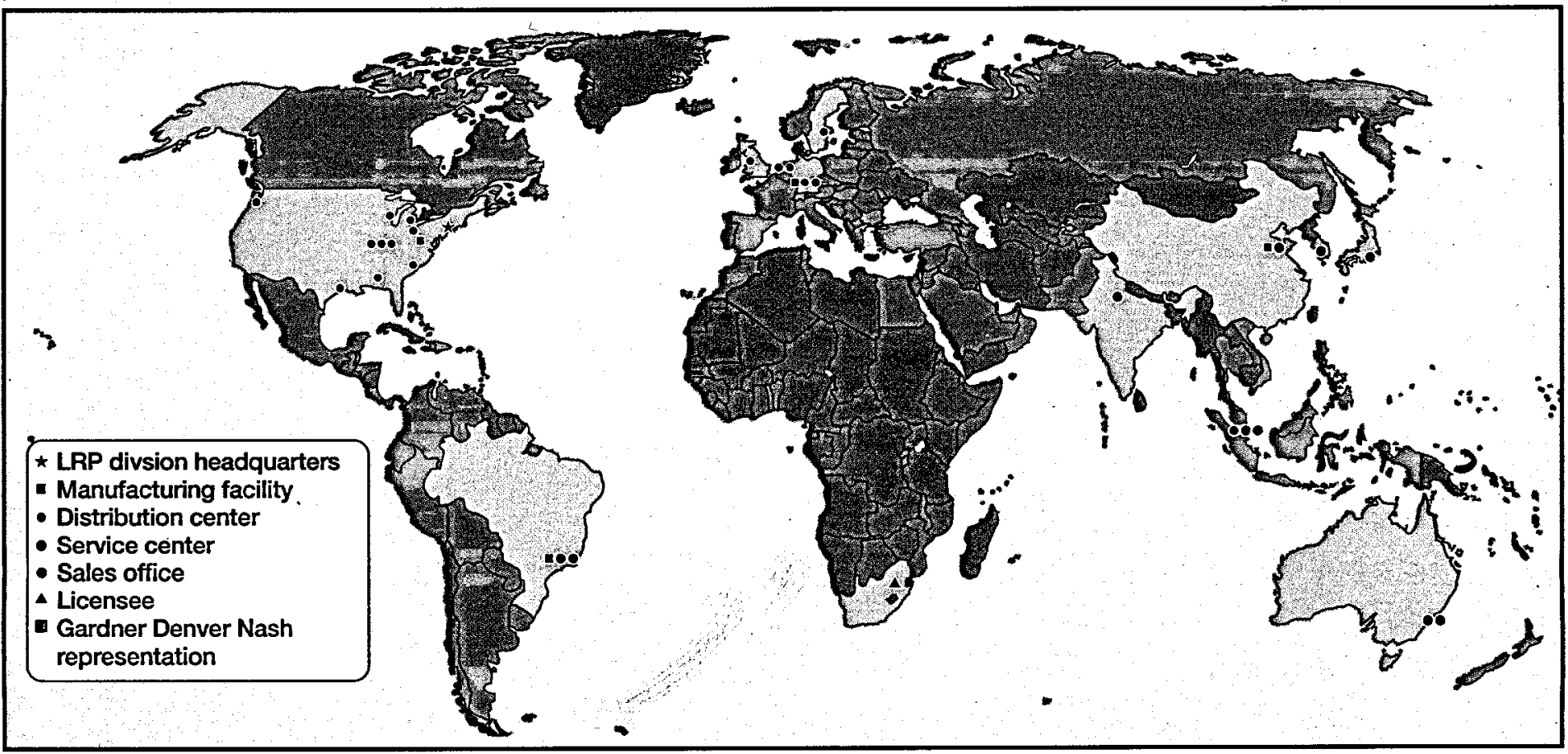

\title{
Gardner Denver Liquid Ring Pump Division
}

\author{
9 Trefoil Drive \\ Trumbull, CT 06611 \\ phone: $\quad 1800553 \mathrm{NASH}$ \\ $+12034593900$ \\ fax: +12034593988 \\ email: nash@gardnerdenver.com \\ www.GardnerDenverNash.com
}

$\because$ Australia, Smithfield, NSW

Gardner Denver Nash Australia Pty. Ltd.

\section{Brazil, Campinas, São Paulo}

Gardner Denver Nash Brasil Industria e Comercio de Bombas Ltda.

China, Boshan

Gardner Denver Nash Machinery Ltd.

England, Winsford, Cheshire
Gardner Denver Nash UK Ltd.

England, Winsford, Ches
Gardner Denver Nash UK Ltd.
Germany, Nürnberg

Gardner Denver Nash

Deutschland GmbH

Japan, Tokyo

Gardner Denver Elmo Japan Ltd.

Korea, Seoul

Gardner Denver Nash Korea Ltd.

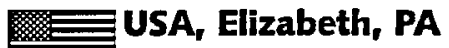

Gardner Denver Nash LLC
Netherlands, Assendelft

Gardner Denver Nash Benelux B.V.
6. Singapore

Gardner Denver Nash Singapore

\section{Sweden, Sollentuna}

Gardner Denver Nash Scandinavia AB

USA, Elizabeth, PA

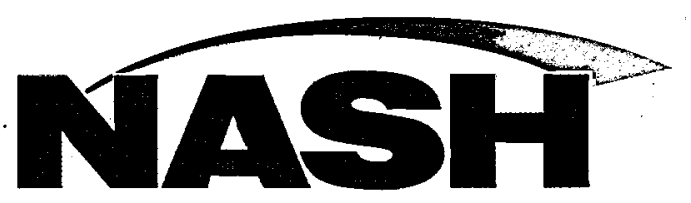

